\title{
MUZEU DE ARTĂ CONTEMPORANĂ LA BUSAN \\ - DE LA TITLU LA PROIECT
}

Conf. dr. arh. Dan Dinoiu

dandinoiu@uauim.ro

INJE UNIVERSITY

GIMHAE , COREEA DE SUD

09/2019-12/2019 


\section{UNIVERSITATEA ȘI ENVIRONMENTUL EI ÎN CONTEXT MAI LARG}

Inje University este o universitate privată sud-coreeană cu campusuri în Gimhae și Busan. Istoria universității a început însă la Seoul, în 1932, ca școala medicala afiliata clinicii înființate acolo de către doctorul Inje Paik, un pionier al medicinii moderne coreene. Clinica a devenit în 1946 Seoul Paik Hospital datorită generozității fondatorului ei, care și-a donat întreaga avere pentru înființarea primei organizații non-profit de acest fel din țară. Dezvoltată de colaboratorii și urmașii săi, rețeaua spitalicească a ajuns la cinci unități răspândite în toata Coreea iar școala a fost transformată în universitate, Inje University având astăzi 7 colegii, 14 facultăți, 33 departamente, aproximativ 16000 studenți înscriși în programe universitare și postuniversitare și aproximativ 1000 cadre didactice. Cele două departamente mai interesante pentru noi, unde mi-am și desfășurat activitatea, Department of Architecture și Department of U-Design fac parte din College of Engineering, respectiv College of Design. Campusul din Gimhae (Fig. 1), cel mai mare

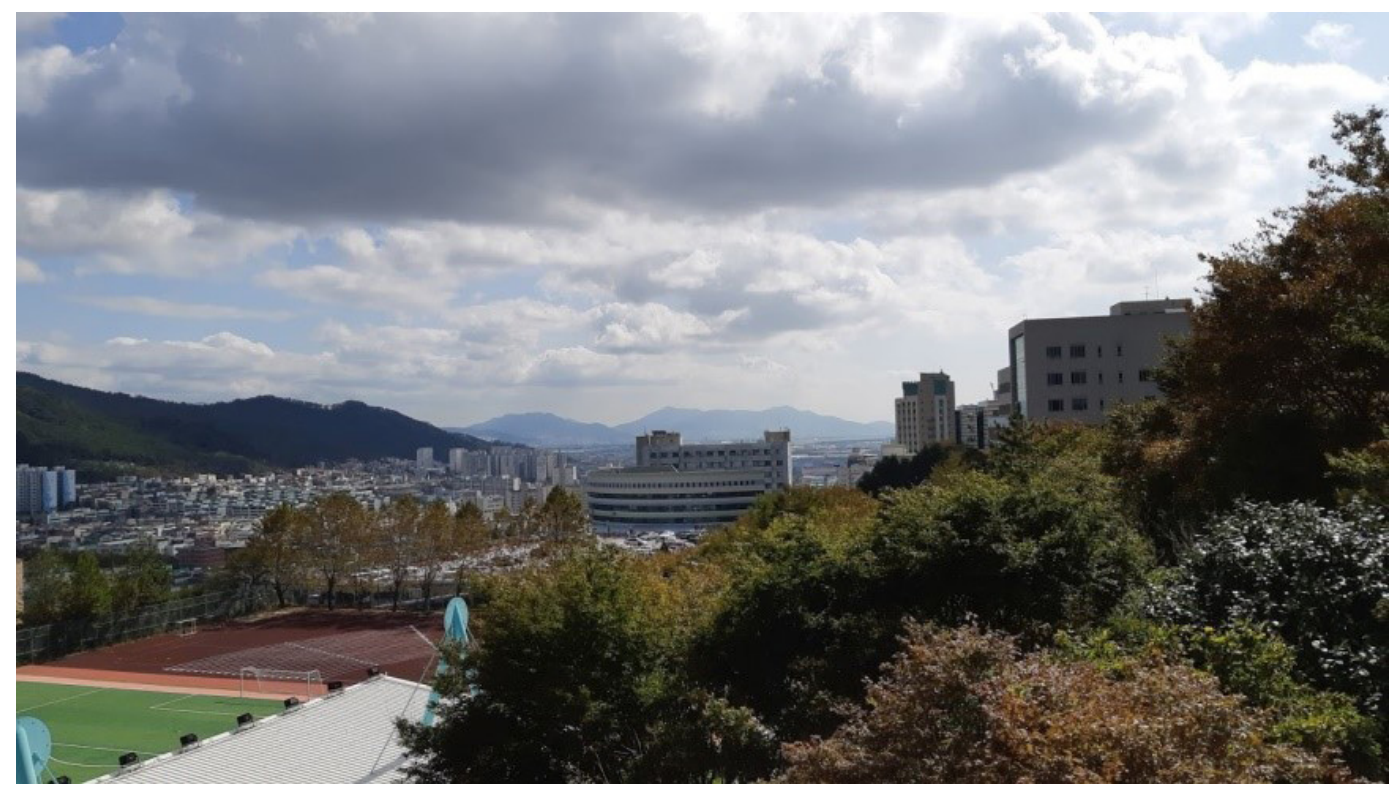

Fig. 1. Gimhae. Campusul Inje University din Gimhae-si, Gyeongsangnam-do, construit în partea noua a orașului, la poalele muntelui Sineosan Seobong. La orizont se vede orașul Busan, muntele Geumjeongsan, râul Nakdong și Marea Japoniei. În stânga imaginii, pe versant muntos se află trei dintre cele mai vechi temple budiste din regiune, așezate discret pe mici terase stâncoase și în contrast cu omniprezența bisericilor, Coreea fiind azi o țară preponderent creștină. 
Fig. 2. Busan. Podul Gwangandaegyo, al doilea pod ca lungime din Coreea după cel care leagă aeroportul internațional Incheon de seoul, face legătura între uscat și insula Yeongdo. In spate, muntele Geumjeongsan.

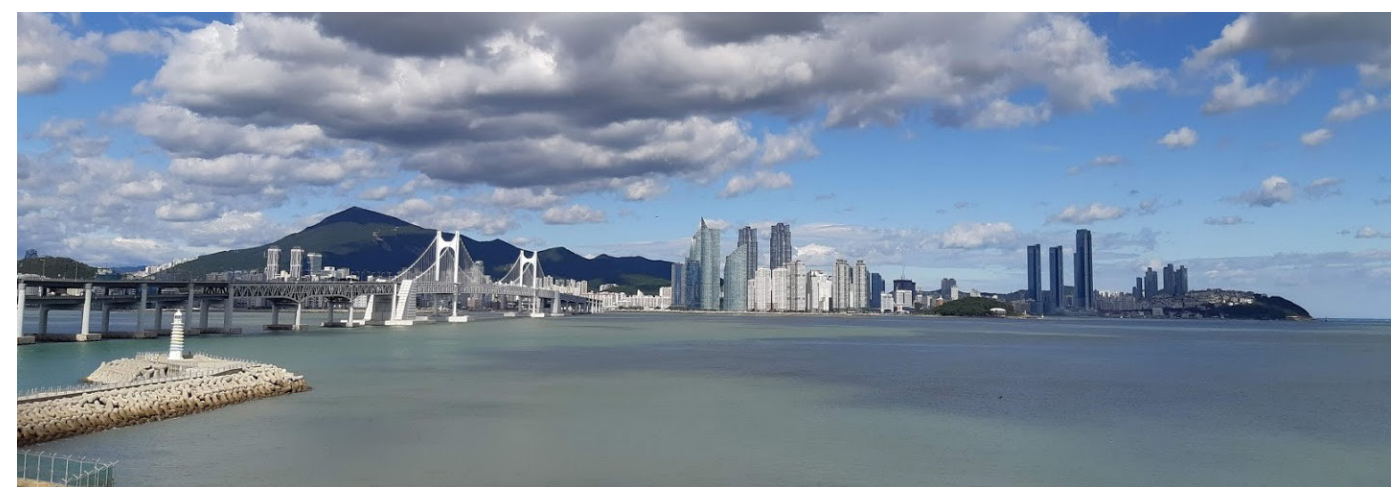

campus al universității, are o suprafață de aproximativ $320.000 \mathrm{mp}$ și conține, în afară de clădirile facultăților și administrației, cazare pentru aproximativ 2500 de studenți coreeni și străini (cei mai mulți veniți din China), o bibliotecă cu peste 800.000 volume, numeroase clădiri destinate vieții sociale și culturale, cantine și cofetării, magazine, o bază sportivă impresionantă și propria linie de autobuz care face legătura între campus și principalele mijloace de transport public din zonă.

Gimhae este situat în imediata vecinătate a Busanului, cu care împarte malurile râului Nakdong, aeroportul, o parte din infrastructura de transport precum și o bună parte din facilitățile universitare. Adăpostit azi între munți și râu, Gimhae a fost cândva port la Marea Japoniei dar a pierdut contactul cu litoralul din cauza aluviunilor aduse de râul Nakdong. Pe când era încă port, orașul a fost capitala legendarului rege Suro și al reginei Heo, ambii având monumente funerare fabuloase în oraș. De origine posibil indiană, regina a sosit la Gimhae chiar pe mare cu o corabie, ducând cu ea o pagodă din piatră în stil indian (prima din regiune) pentru a calma vânturile și valurile, pe care a dăruit-o apoi regelui Suro. Astăzi orașul pare retras între munți și mulțumit cu statutul de oraș universitar, subordonat Busanului.

Pe cealaltă parte, Busan a profitat de statutul de port, a înaintat continuu către apă, ocupând toate micile insule din jur și, odată cu secolul al XV-lea, a devenit principalul hub comercial destinat comerțului cu Japonia. Administrația coreeană a permis japonezilor să se stabilească în oraș și în alte câteva localități din jur, ceea ce a dus la accelerarea dezvoltării întregii regiuni și la schimburi culturale majore între cele două națiuni. Acesta nu a fost însă primul episod semnificativ al interacțiunilor culturale dintre coreeni și japonezi, până la urmă budismul a ajuns în Japonia prin intermediul Coreei. În fine, după turbulențe politice și militare dintre coreeni și japonezi și după o izolare față de vest comparabilă cu a Japoniei, Busan a renăscut în secolul al XIX-lea când a (re)devenit primul port internațional a Coreei, statut pe care îl deține și azi (Fig. 2). 
Odată cu sfârșitul războiului coreean, Busan (fiind singurul mare oraș al sudului care nu a fost niciodată ocupat de armata nord-coreeană) s-a transformat într-o metropolă de succes, și-a urbanizat salba de plaje și faleze stâncoase pe care o are la Marea Japoniei și și-a dezvoltat o infrastructură extraordinară care a permis naturii să coexiste cu orașul într-o relație de simbioză unică (Fig. 3, Fig. 4).

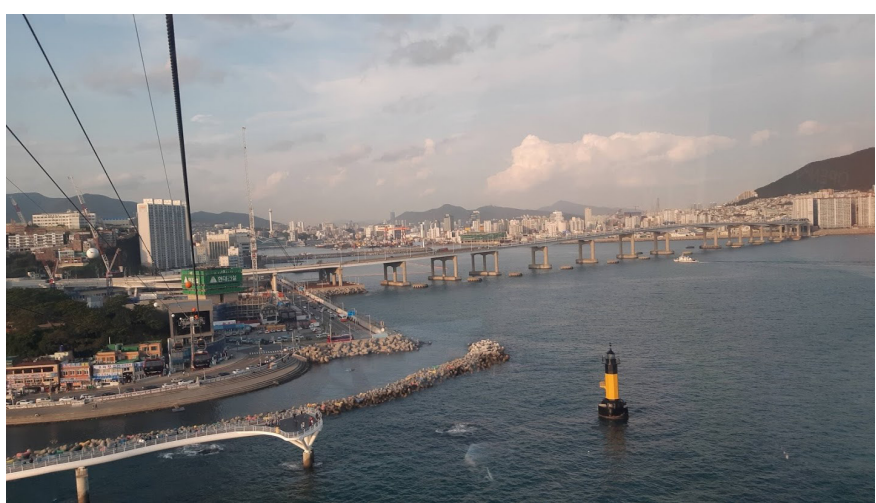

Fig. 3. Busan. Stația gondolei care leagă Songdo, una din plajele populare ale orașului, și Amnam, o faleză stâncoasă devenită parcul natural. În planul doi se vede Podul Namhang și muntele Geumjeongsan.

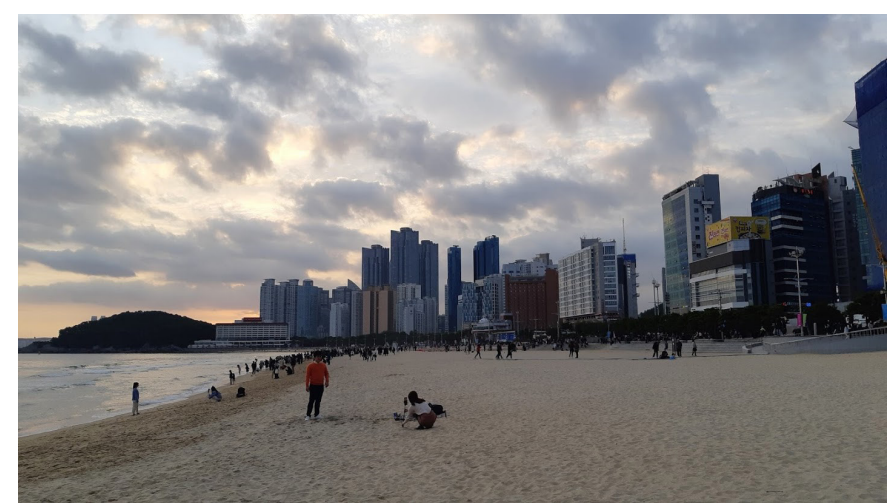

Fig. 4. Busan, cartierul Heundae. Plaja Heundae este legată de situl proiectului de atelier, The Old Heundae Train Station, printr-o Rambla-copie a Ramblei barceloneze. Această plajă este locul unde relația dintre natural și mineral este cel mai bine tinută în mână, iar atmosfera seamănă bine cu cea de pe Passeig Marítim.

În ecosistemul coreean însă, Busan se află în competiție acerbă cu Seoul. Rivalitatea dintre cele două orașe are cauze ce se pierd în istorie, iar relația dintre ele este adesea comparată cu relația dintre Barcelona și Madrid. Ca și în cazul Spaniei, Busan joacă rolul actorului economic mai mic dar mai ambițios, dornic să se afirme în competiția cu gigantul care este Seoul. Asemănarea Busanului cu Barcelona nu se oprește aici: orașul a copiat de-a dreptul modelul catalan în multe privințe, grefând părți din Barcelona în propriul țesut (Rambla și mecanismul plajelor urbane, de exemplu).

În plus, ca și în cazul spaniol, Busan se luptă cu Seoul pentru a deveni capitala culturală (și turistică...) a Coreei de Sud. în această luptă, arhitectura și urbanismul joacă un rol cheie, Busan Cinema Center și festivalul de cinema BIFF care se desfășoară acolo fiind exemple în acest sens (Fig. 5). Clădirea centrului cinematografic a bătut record după record, unele nedorite (a depășit în mod repetat bugetul dar - și asta este cel mai important - ea a ilustrat încă din 2011 direcția în care se va îndrepta orașul și în special cartierul Heundae, locul de desfășurare al proiectului de atelier pe care l-am coordonat la atelier). Festivalul a devenit în ultimii ani unul dintre cele mai importante din întreaga 
Asie, iar cinematografia coreeană a luat avânt (Fig. 6), devansând cinematografii cu prestigiu, precum cea japoneză. Oferta turistică a orașului a fost astfel diversificată, de la plajă la cultura înaltă (trecând prin gastronomie și comerț high-end), în același fel în care au făcut-o și Barcelona în Europa.

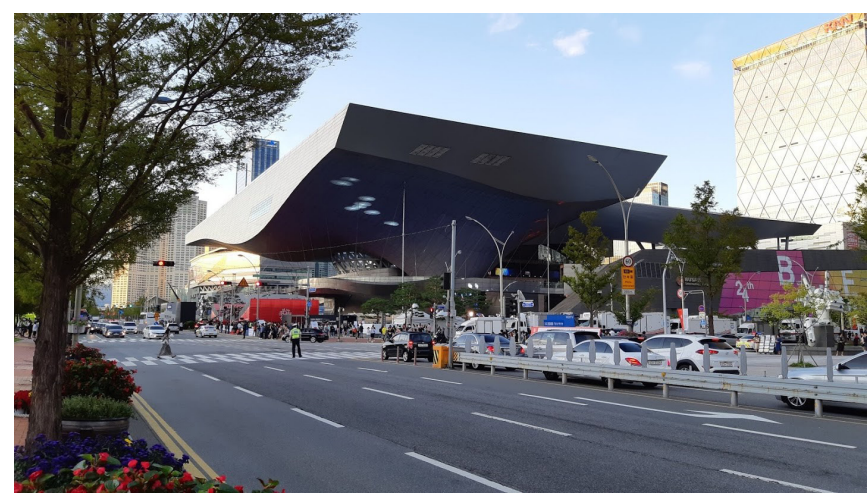

Fig. 6. Posterul filmului Parasite. Filmul a câștigat 4 premii și doua nominalizări la Oscar in 2020, printre care cel pentru cel mai bun film străin și a fost prezentat in cadrul festivalului BIFF, ediția 2019. sursa:

https://www.vintagemovieposters. co.uk/shop/parasite-movieposter-2/ la data de 6 septembrie 2020.
Fig. 5. Busan, cartierul Haeundae. Foyerul urban al Centrului de Cinema Busan (BBC), în așteptarea deschiderii festivalului de cinema internațional BIFF' 2019. Clădirea a fost proiectată de biroul austriac Coop Himmelb(l)au și dată în folosință în 2011. Copertina este tinută de cea mai mare consolă din lume și beneficiază de un sistem hidraulic de reazeme de siguranță, care se ridica automat din pardoseala foyerului în caz de taifun sau cutremur.

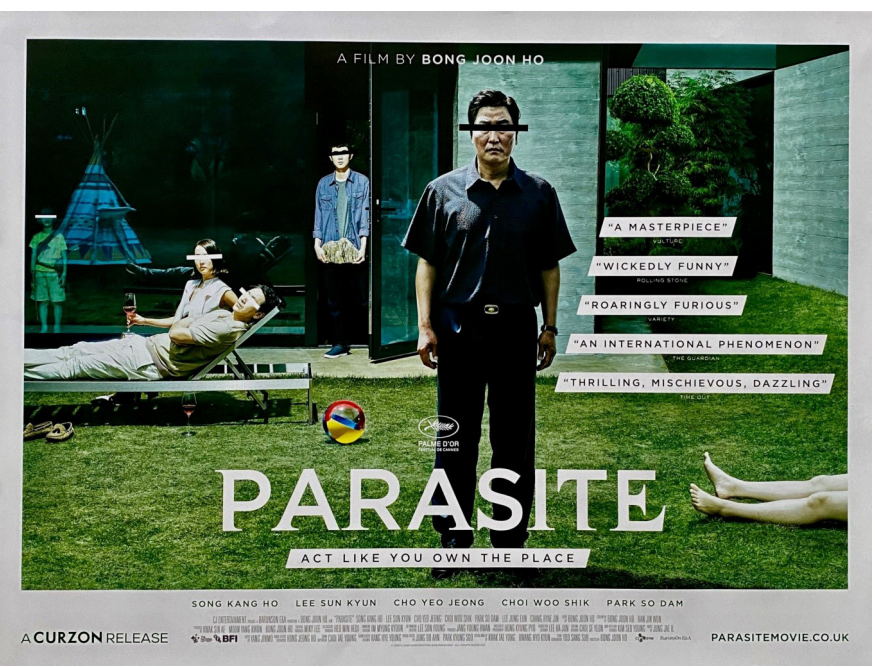

Pe de o parte, lupta Busanului cu Seoulul seamănă cu lupta dintre David și Goliat, Seoul fiind un colos demografic și economic care concentrează jumătate din populația de 50 de milioane de locuitori a Coreei și a patra economie metropolitană a lumii, după Tokyo, New York City și Los Angeles.

Pe de alta parte însă, Seoul și Busan sunt prinse amândouă în capcana arhitecturii secolului al XX-lea, cea care le-a asigurat succesul de până acum, dar care și-a atins limitele. Prin urmare ambele orașe sunt sortite reinventării și învățării de lucruri noi, unul de la altul chiar, pentru a rămâne relevante în continuare.

Orașele coreene, având pe Seoul și Busan în prima linie, au fost modernizate pe baza principiilor moderniste ale lui Le Corbusier, venite pe filiera americană, layerul istoric 
fiind cam peste tot neglijat, neglijabil sau inexistent. Tot pe filiera americană a pătruns în Coreea și cultura mașinii (bicicleta este încă inexistentă în peisajul urban coreean de azi, în ciuda faptului că în Europa a provocat deja de ceva timp o revoluție în percepția spațiului urban și în modul cum orașele se raportează la mobilitatea cetățenilor săi!). Acest proiect de modernizare, aplicat la scara națională, extrem de pragmatic și eficient, a ajutat procesul de urbanizare al țării și a dus la succesul economic de azi (Coreea este a patra economie asiatică și a douăsprezecea economie a lumii, plecând, după războiul coreean, de pe una din ultimele poziții la nivel mondial). în același timp însă, acest proiect reprezintă azi principalul obstacol pe care orașele coreene trebuie să-l învingă pentru a se reinventa ca „orașe prietenoase” de secol XXI. Într-un fel, Coreea este rezultatul unui urbanism mai degrabă american decât european, cu toate plusurile și minusurile acestei situații. În plus, cultura coreeană nu înțelege spațiul public în felul în care îl înțeleg europenii: piața publică este practic inexistentă, piața însăși fiind o idee importată relativ recent și care a rămas mai degrabă o formă fără fond decât un spațiu efectiv al publicului. Spațiul publicului coreean este mai degrabă strada comercială și curtea privată care devine din când în când spațiu colectiv. Cultura urbană coreeană are însă o relație mult mai nuanțată și, pe undeva mai bogată, cu natura, pe care o acceptă în orașele lor mai ușor și la o scară mai mare decât europenii (aceste diferențe culturale mi-au creat cele mai mari dificultăți, dar și oportunități suplimentare, în coordonarea activității de la atelier).

Seoul, având în frunte un primar extrem de ambițios și interesat de urbanism, s-a angajat încă din 2015 într-un proces de regenerare urbană de proporții odată cu lansarea programului Urban regeneration: 27 projects for Seoul și odată cu lansarea primei ediții a Bienalei de arhitectură și urbanism de la Seoul (SAUB), din 2017. Cel mai ilustrativ proiect

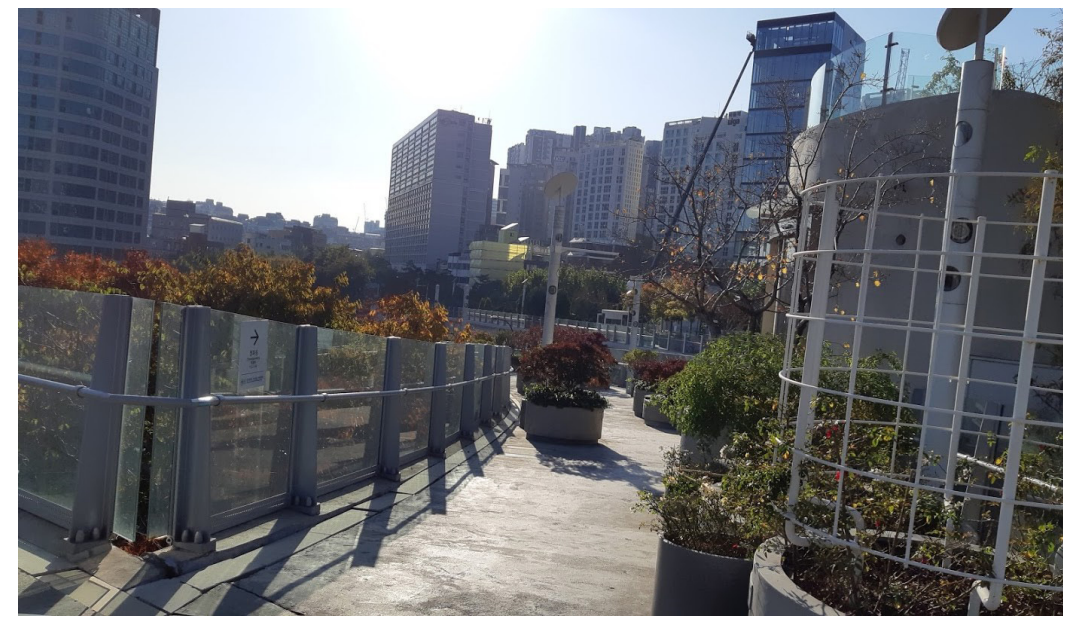

dintre cele 27, care a și fost subiectul unuia dintre tururile organizate cu ocazia bienalei din 2017, este Seoullo 7017 (Fig. 7).

Fig. 7. Seoullo 7017, Seoul. Conversia unui vechi pasaj rutier în grădină botanică și traseu pietonal, realizată de MVRDV in 2017. Arhitecții olandezi au eliminat pur și simplu mașinile de pe pasajul rutier suspendat peste zona gării centrale din seoul și le-au înlocuit cu o grădină botanică prin intermediul căreia pietonii pot traversa zona acestui imens nod intermodal conectați numai la functiuni specifice mersului pe jos. Últerior, o serie de clădiri adiacente traseului și-a mutat funcțiunile publice (si) la etajul 1 și s-au conectat cu traseul. 
Pentru a face mai clară consecvența întregului proces, trebuie să spun că cea de-a doua bienală, cea din 2019, a avut titlul Collective City (Fig. 8), iar anul viitor urmează o a treia ediție, cu titlul CROSSROADS: Building the Resilient City, care urmărește aceeași linie a reinventării urbane și este curatoriată de Dominique Perrault. Perrault cunoaște în profunzime orașul Seoul deoarece a proiectat aici o extindere a campusului universității EWHA în care curtea interioară a campusului formează o curte-buzunar a orașului în care publicul are acces neîngrădit. Proiectul lui Perrault pare să fi servit drept exemplu, ulterior alte proiecte au folosit aceeași strategie, cel mai cunoscut dintre ele fiind Dongdaemun Design Plaza al lui Zaha Hadid. În fine, ca să închei rotund această digresiune despre contextul arhitectural al universității, clădirea KB Youth Step (Fig. 9), care folosește aceleași principii ale conexiunii urbane cu orașul, convertind o parte a spațiului interior al unei foste sucursale de bancă în scara-buzunar accesibilă publicului direct din stradă, este proiectată de biroul de proiectare al Facultății de Arhitectură din cadrul Universității Hongik.

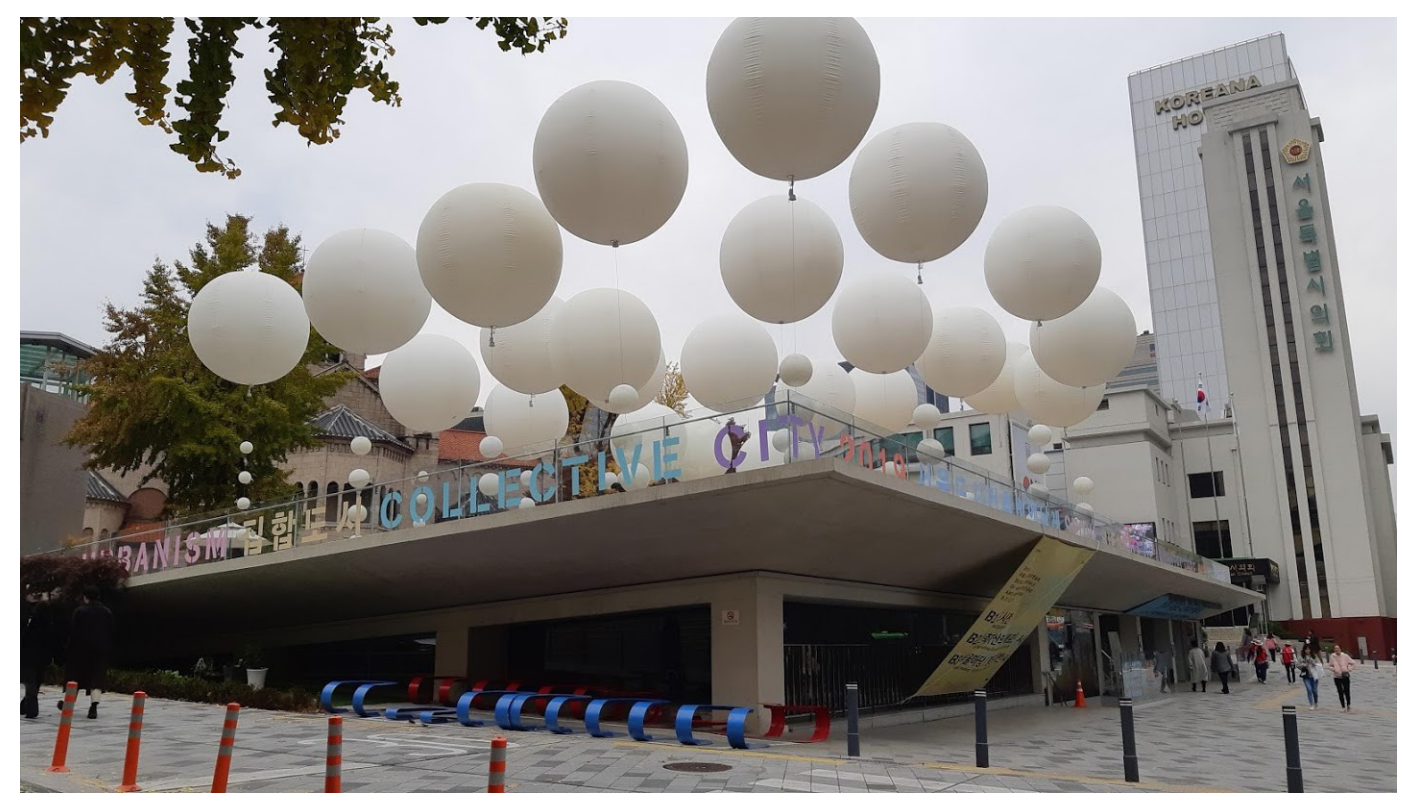

Fig. 8. Spațiul expozițional al Bienalei de Arhitectură și Urbanism Seoul 2019 (SBAU) cu titlul Colective City. Clădirea, care aparține ordinului arhitecților, este o conversie a ruinelor unei clădiri interbelice de birouri aparținând poștei guvernului de ocupație japonez în spațiu expozițional. Clădirea art-deco de alături, cea cu turn pe colt, este sediul Consiliului Metropolitan al orașului Seoul, ceea ce spune, cred, foarte multe despre seriozitatea cu care orașul privește arhitectura și urbanismul. În subsol este instalată, pe durata bienalei, o amplă expoziție dedicată Barcelonei și modului în care orașul va coopera cu natura în viitor. 


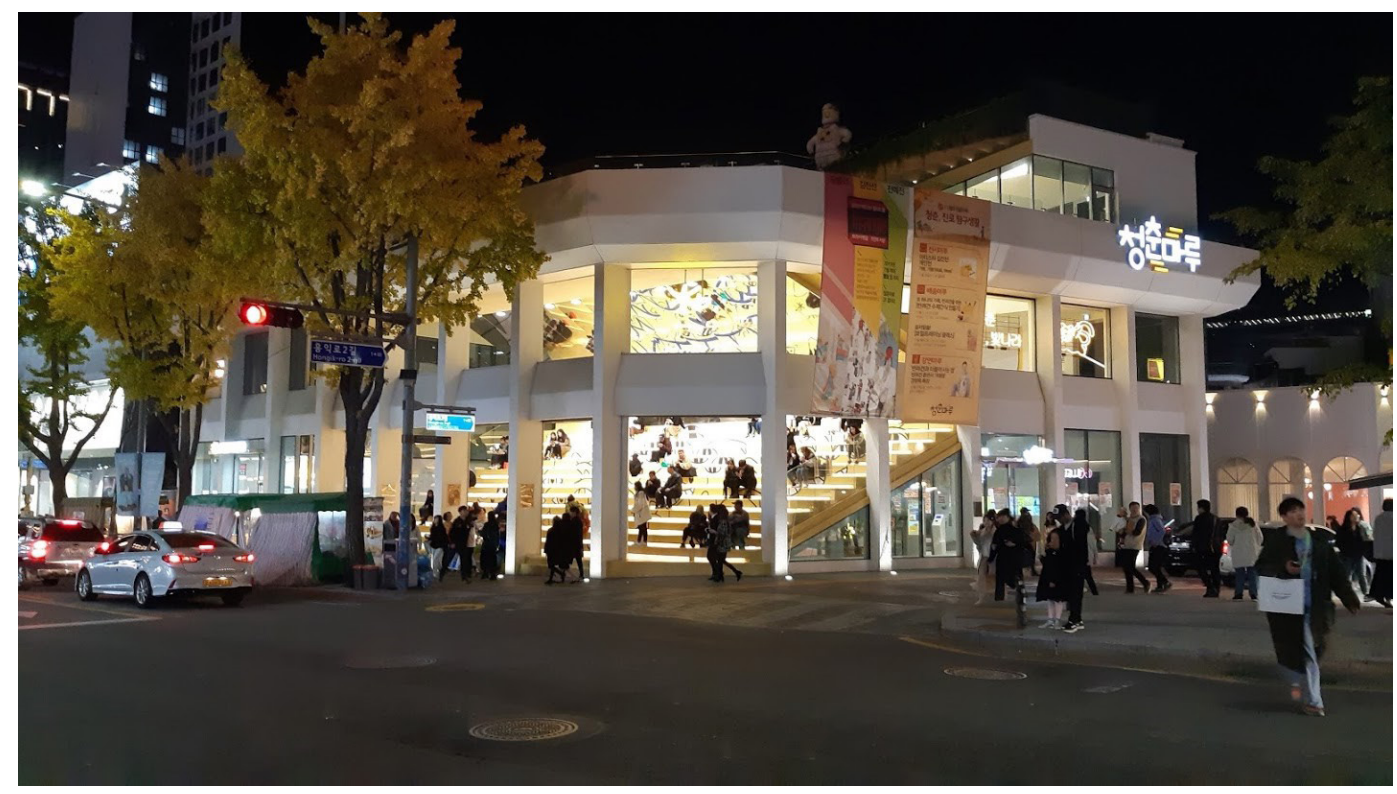

Fig. 9. KB Youth Step, Seoul. Clădirea, o conversie, adăpostește la interior o scară-gradenă și spații culturale.

\section{2. ÎNDRUMARE ATELIER DE ARHITECTURĂ - GENERALITÁȚI}

Conform site-ului universității Inje, Departamentul de Arhitectură „oferă programe de studii de 5 ani și de 4 ani. Programul de 5 ani pregătește studenți pentru proiectarea de arhitectura, încurajând creativitatea, planificarea, proiectarea propriu-zisa și munca în sistem de atelier de proiectare. Pentru a îndeplini standardele educaționale internaționale, curriculum urmărește criteriile Uniunii Internaționale a Arhitecților (UIA). Programul de 4 ani oferă partea inginereasca a arhitecturii prin intermediul unor cursuri mai aprofundate pentru a pregăti arhitecți-ingineri competitivi."

Coordonatorii atelierelor sunt titulari cu contract ai universității, recrutați din rândul tinerilor profesioniști cu rezultate (proiecte laureate, concursuri câștigate) care au beneficiat de o educație academică extinsă. Aceștia renunță obligatoriu la cariera profesională pe perioada contractului pentru a se ocupa exclusiv de activitatea universitară. Nu am idee cum sunt admiși în mod efectiv în facultate studenții, însă în mod clar ei au o educație umanistă solidă și mulți dintre ei o pregătire artistică excelentă. 
Fig. 10. Jurizarea finală. Ambii coordonatori coreeni de ateliere erau absolventi ai universității Inje și a unei a doua universități de arhitectură, din Franța.

Programul universitar începe, din cauza anotimpului taifunurilor, în Martie și se termina în Decembrie, cu o vacanță scurtă în vară și una lungă în iarnă. În programul de 5 ani, departamentul are cam 30 de studenți pe an, la care se adaugă câțiva bursieri străini, împărțiți în 3 ateliere cu minim 10 studenți fiecare.

Atelierul este coordonat de cate un singur cadru didactic care acordă și notele finale studenților, în urma unei jurizări comune cu ceilalți doi coordonatori din ateliere (Fig. 10). Nota poate să oglindească prezența la atelier sau prezentarea finală (20\% din nota finală se poate referi la prezență și $40 \%$ la prezentare), dar acest aspect este lăsat la latitudinea coordonatorului. Există un barem minim de prezente pe semestru/proiect dar studenții sunt în general prezenți la fiecare atelier și pe toata durata lui, iar gradul de interes al studenților pentru discuțiile cu coordonatorul atelierului este maxim.

Studenții au câte un proiect de atelier pe semestru, dezvoltat pe parcursul a 15 săptămâni, și au drept de opțiune la începutul fiecărui proiect. Programul de atelier presupune o întâlnire săptămânala, la care se poate adăuga o a doua întâlnire, suplimentară, în funcție de situație și de faza în care se află proiectul. În general, coordonatorii atelierelor stabilesc cu precizie conținutul fiecărei întâlniri, în funcție de faza și de natura proiectului. Coordonatorii de ateliere organizează de comun acord o jurizare intermediară, fără note, unde sunt discutate toate conceptele și ideile dezvoltate până atunci. Jurizările intermediare se fac pe baza unui amplu material tipărit pe format A4, însoțite de foarte multe machete conceptuale, iar jurizările finale pe baza unui panou unic A1, tipărit pe suport rigid și a unui număr (uneori foarte mare!) de machete de prezentare. Comisiile nu se formalizează referitor la numărul și conținutul pieselor, sau la tehnica de prezentare

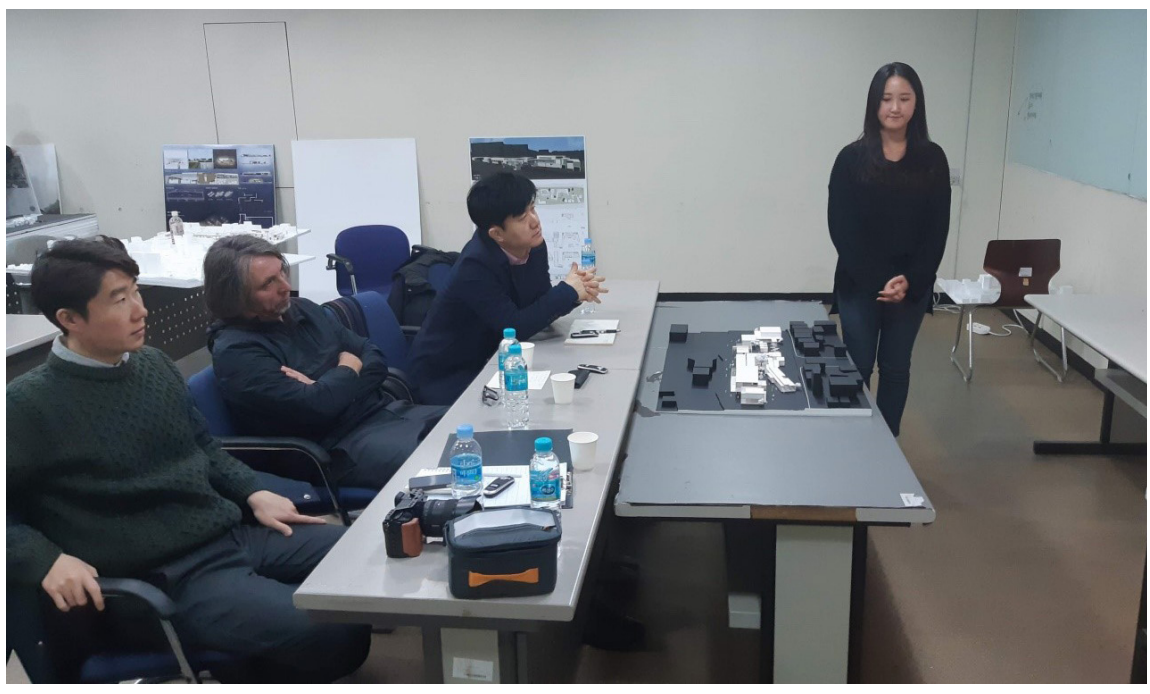
însă nu accepta proiecții video și videoclipuri.

Eu am coordonat un atelier de anul 3, semestrul 2, unde am avut 12 studenți, inclusiv un bursier de origine chineză de la TU Delft) (Fig. 11). Toți cei 12 studenți au optat să ajungă la atelierul meu, ceea ce, pe de o parte, a fost un avantaj, pentru că erau motivați să se confrunte cu un profesor și o metoda străină și, pe de alta parte, un dezavantaj, pentru că nu toți stăpâneau limba engleză suficient de bine. 


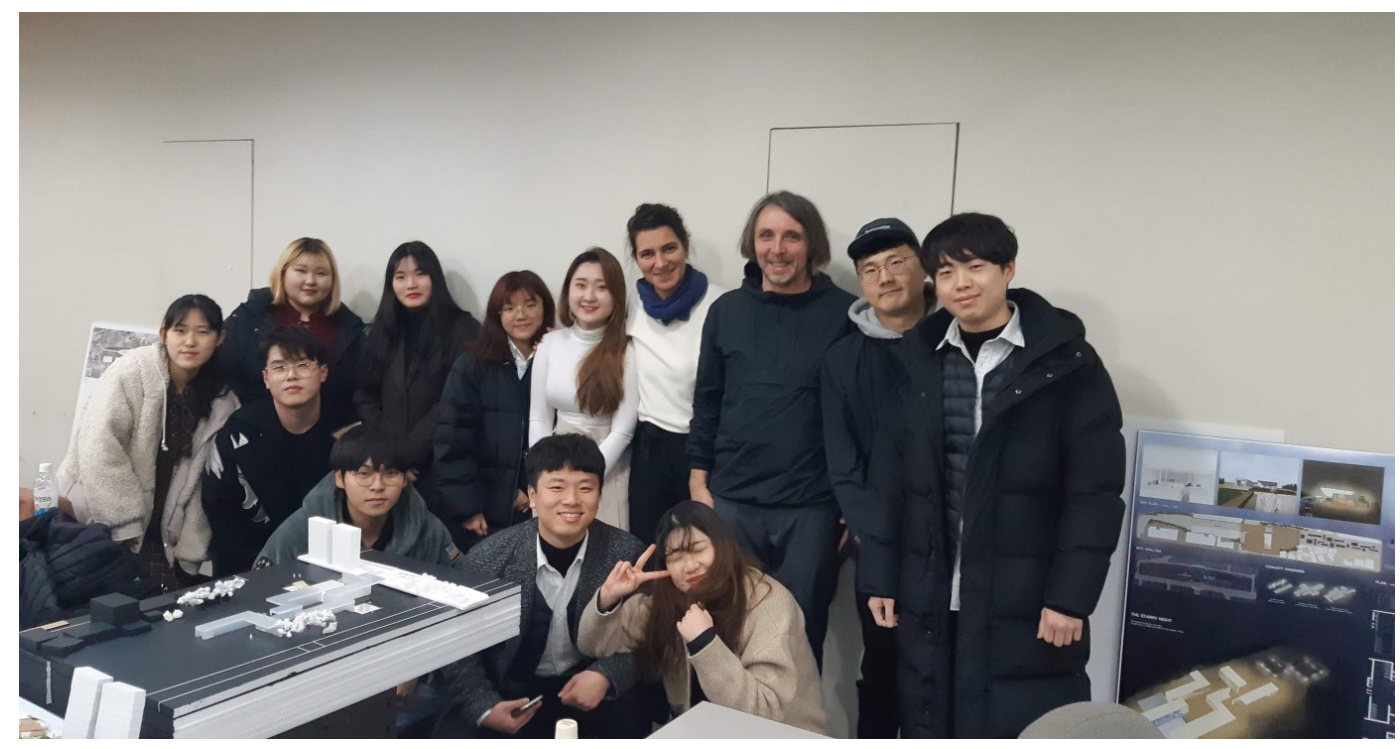

Fig. 11. Atelierul de arhitectură, după jurizarea finală. Proiectele au fost apreciate și notele au fost mari, ceea ce explica probabil și zâmbetele de pe fețele tuturor

\section{TEMA}

Tema proiectului de anul 3 prevedea proiectarea unei galerii de artă sau a unui muzeu în suprafață de aproximativ 5000 mp în cartierul de elită al Busanului, Heundae, pe o porțiune de cale ferată închisă și abandonată acum, care conține și vechea stație de tren Old Heundae. Suprafața și programul, deși indicate în temă, erau absolut secundare, scopul principal fiind să operezi într-un țesut extrem de dinamic și complex, în care există zone absolut noi alături de rămășițe abandonate, rămase din layerele anterioare ale orașului. Partea cea mai interesantă a temei, afișată în josul paginii în Tabelul 1, este compusă din obiectivele și desfășurătorul procesului, care reflectă destul de clar metoda urmărită la atelier. Evident, coordonatorii atelierelor au libertatea de a amenda metoda de dezvoltare a proiectului și desfășurătorul, în funcție de interese și de situație, singurele date fixe fiind jurizările intermediare și finale stabilite de comun acord de cei trei coordonatori de atelier. 
Tabelul 1. Obiectivele și desfășurătorul proiectului de arhitectura numărul 6, anul 3, semestrul 2

\begin{tabular}{|c|c|c|c|}
\hline $\begin{array}{l}\text { Informații } \\
\text { despre proiect }\end{array}$ & \multicolumn{2}{|c|}{$\begin{array}{l}\text { Titlul proiectului } \\
\text { Curriculum } \\
\text { Credite } \\
\text { Departament } \\
\text { Prioritate } \\
\text { Limba } \\
\text { Metode de predare }\end{array}$} & $\begin{array}{l}\text { Proiect de arhitectura numărul } 6 \\
\text { Undergraduate } \\
10 \\
\text { Departamentul de ArhitecturĂ }\end{array}$ \\
\hline $\begin{array}{l}\text { Liniile } \\
\text { directoare ale } \\
\text { proiectului }\end{array}$ & \multicolumn{3}{|c|}{$\begin{array}{l}\text { Actualul proiect va necesita un proces de proiectare arhitecturală } \\
\text { realizat pe baza teoriei de arhitectura acumulata până acum. } \\
\text { Studenții își vor însuși procesul de proiectare și teoria spațiului de } \\
\text { arhitectura prin intermediul unei clădiri de muzeu. } \\
\text { Studenții vor învăța despre funcționalitate, proiectare conceptuala } \\
\text { și obiecte concrete investigând, analizând și criticând precedentele } \\
\text { muzeale. }\end{array}$} \\
\hline $\begin{array}{l}\text { Obiectivele } \\
\text { proiectului }\end{array}$ & \multicolumn{3}{|c|}{$\begin{array}{l}\text { Cum sa folosești o imagine, o machetă și media digitala. } \\
\text { Cum sa înțelegi toate normativele și standardele practice de } \\
\text { proiectare. } \\
\text { Cum sa colectezi și sa analizezi informațiile naturale și } \\
\text { environmentale și cum să le integrezi în proiect. } \\
\text { Cum să colaborezi cu colegii prin intermediul activităților bazate pe } \\
\text { munca de echipă. }\end{array}$} \\
\hline Notare & \multicolumn{3}{|c|}{$\begin{array}{l}\text { Prezența (20\%), procesul de proiectare (40\%), prezentarea finală } \\
(40 \%) \text {. }\end{array}$} \\
\hline \multirow[t]{4}{*}{$\begin{array}{l}\text { Desfășurătorul } \\
\text { proiectului pe } \\
\text { săptămâni }\end{array}$} & $\begin{array}{l}1 \\
2\end{array}$ & $\begin{array}{l}\text { Lectură și discuție } \\
\text { Prezentare, discuție și } \\
\text { activitate practica }\end{array}$ & \begin{tabular}{|l} 
Introducere \\
Analiza funcțională
\end{tabular} \\
\hline & 3 & $\begin{array}{l}\text { Prezentare, discuție și } \\
\text { activitate practică }\end{array}$ & Analiza sitului \\
\hline & 4 & $\begin{array}{l}\text { Prezentare, discuț̆ie și } \\
\text { activitate practică }\end{array}$ & Design conceptual - 1 \\
\hline & 5 & $\begin{array}{l}\text { Prezentare, discuție și } \\
\text { activitate practică }\end{array}$ & Design conceptual - 2 \\
\hline
\end{tabular}




\begin{tabular}{|l|l|l|l|}
\hline & 6 & $\begin{array}{l}\text { Prezentare, discuție și } \\
\text { activitate practică }\end{array}$ & Program spațial \\
\hline & 7 & $\begin{array}{l}\text { Prezentare, discuție și } \\
\text { activitate practică }\end{array}$ & Plan de situație \\
\hline & 8 & $\begin{array}{l}\text { Prezentare, discuție și } \\
\text { activitate practică }\end{array}$ & Dezvoltarea proiectului - 1 \\
\hline & 9 & $\begin{array}{l}\text { Prezentare, discuție și } \\
\text { activitate practică }\end{array}$ & Dezvoltarea proiectului - 2 \\
\hline 10 & $\begin{array}{l}\text { Prezentare, discuție și } \\
\text { activitate practică }\end{array}$ & Dezvoltarea proiectului - 3 \\
\hline 11 & $\begin{array}{l}\text { Prezentare, discuție și } \\
\text { activitate practică }\end{array}$ & Dezvoltarea proiectului - 4 \\
\hline 12 & $\begin{array}{l}\text { Prezentare, discuție și } \\
\text { activitate practica }\end{array}$ & Detalierea parțială a proiectului - 1 \\
\hline 13 & $\begin{array}{l}\text { Prezentare, discuție și } \\
\text { activitate practică }\end{array}$ & Detalierea parțială a proiectului - 2 \\
\hline 14 & $\begin{array}{l}\text { Prezentare, discuție și } \\
\text { activitate practică }\end{array}$ & Prezentare \\
\hline 15 & \begin{tabular}{l} 
Prezentare \\
\hline
\end{tabular} & Jurizarea finală \\
\hline
\end{tabular}

Situl proiectului este localizat la capătul dinspre oraș al "Ramblei" (Fig. 12), un sharespace pentru oameni și automobile copiat după modelul barcelonez care sfârșește în plaja Heundae, cea mai luxoasă plajă a orașului. Locul este, de fapt, o porțiune de câteva sute de metri de cale ferată abandonată, lângă care exista încă vechea stație de tren Old Heundae Train Station, abandonată și ea (Fig. 13, 14, 15, 16). Clădirea propriu-zisa a stației de tren, mai degrabă de dimensiunile unei halte și acoperită cu un acoperiș caraghios în stil pagodă, a fost construită de guvernul japonez de ocupație în perioada interbelică și nu are nicio valoare; calea ferată ce urmărește coasta pe câțiva kilometri buni înainte de a înainte intra în oraș, apoi traversează orașul pe un traseu sinuos, este însă un element istoric valoros pe care Busanul l-a transformat deja în mare parte în traseu verde pietonal, în cadrul unui proiect de regenerare urbană ce se vrea un Seoullo 7017 la scară mai mică și așezat pe pământ. Porțiunea stabilită prin temă ca amplasament pentru muzeul de artă este una din ultimele porțiuni rămase neatinse, datorită complexității amplasamentului și potențialului ridicat al sitului aflat în capătul bulevardului care conduce către mare. Copertinele și liniile de cale ferată au dispărut din zonă, dar vechile peroane sunt încă la locul lor și zona este traversată din când în când de riverani. 
Fig. 12. Gunam-ro, Heundae, o copie a Ramblei, face legătura dintre stația de metrou și plaja Heundae.

Fig. 13, 14, 15, 16. Old Heundae train station, Busan. Calea ferată ce traversa odată orașul, și care acum e dezafectată și în mare parte reconvertită în artera verde pietonală, are o istorie deosebită. Era calea prin care soseau călătorii din nordul țării, de la Seoul, în vacanța la mare. Mica stație din apropiere era stația în care coborau cei care doreau să ajungă la plaja Heundae, de aici si numele: Old Heundae.
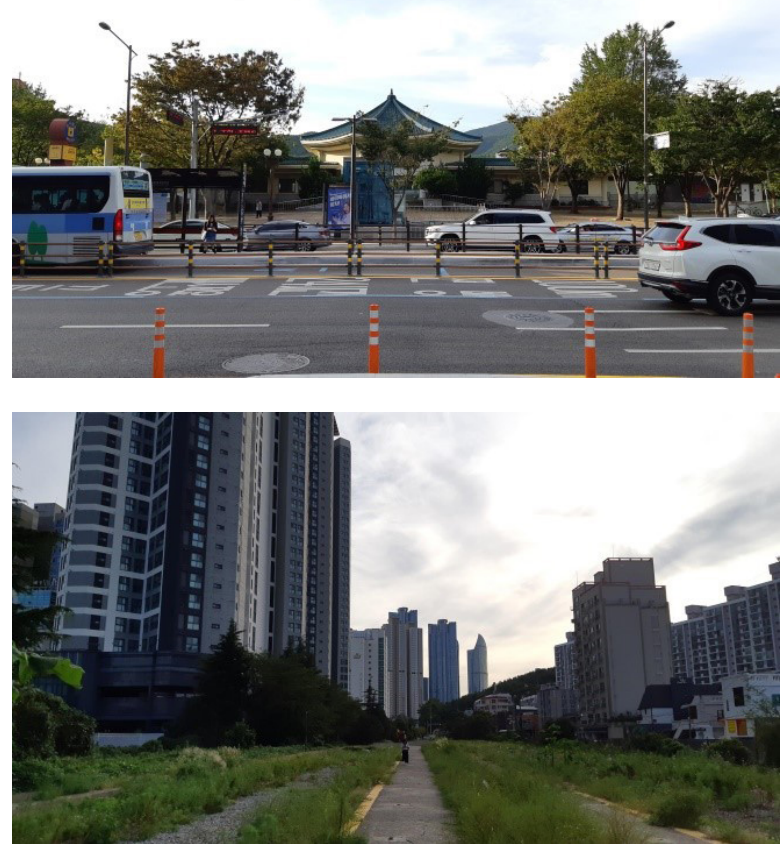
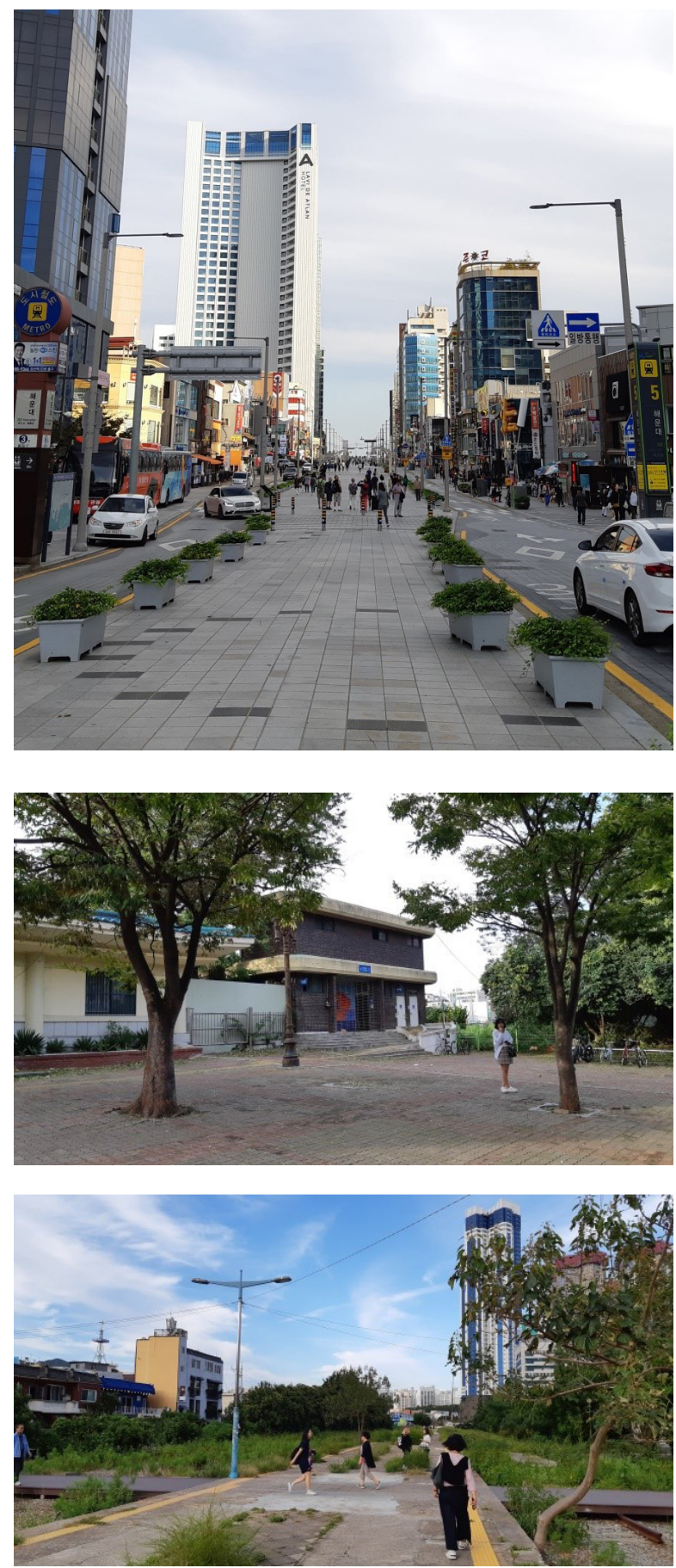


\section{METODA}

Startul procesului de proiectare a fost dat de o primă vizită pe sit, ocazie cu care studenților li s-a cerut să-și aleagă un titlu individual al proiectului, pe baza atitudinii față de sit, și să identifice o listă de probleme majore ale sitului ce necesită rezolvare, pentru ca proiectul să fie unul de succes. Pașii pe care i-am propus atelierului pentru realizarea proiectelor au fost următorii:

1. Titlul. Startul procesului și nu finalul lui.

2. Environmentul. Cadrul în care va funcționa proiectul de arhitectura, atunci când și daca va funcționa.

3. Conceptul. O multitudine de concepte primare și secundare, dezvoltată în siajul titlului, pe baza înțelegerii corecte a environmentului.

4. Proiectul. Un loc și un scenariu așezate în environment.

\section{REZULTATELE FINALE}

Titlurile alese de studenți au fost: The Starry Night, Bouquet, The Rabbit and the Turtle, Slow Dance, The Giving Tree, Toy Story, Scent, Traces of Time, Law of Attraction, New Line, Malfunction Bridge, Movement of Eyes. Trebuie să remarc aici capacitatea uluitoare a studenților coreeni de a sintetiza o idee printr-o sintagmă simplă - titlu - și determinarea lor de a transforma acel titlu într-un proiect de arhitectură (Fig. 17, 18).

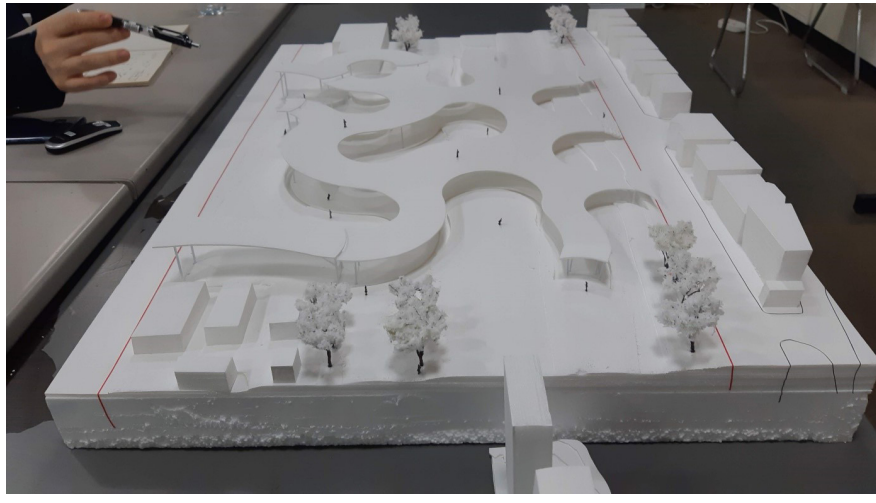

Fig. 17. Scent, faza finală.

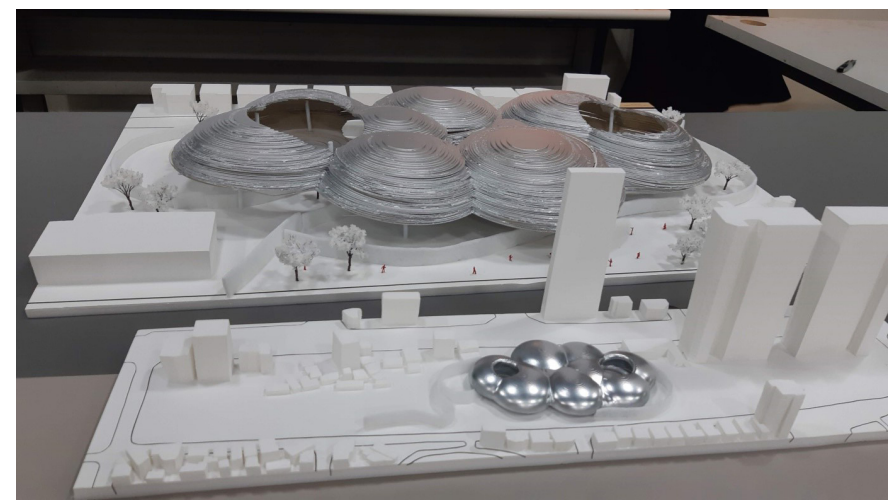

Fig. 18. Bouquet, faza finală 


\section{CONCLUZII}

După vizionarea celor doua jurizări, și după ce am văzut proiectele din anii precedenți ale studenților mei, pot spune că diferența majoră dintre Inje University și UAUIM constă în elaborarea proiectului în faza conceptuală. Studenții coreeni sunt îndrumați să se concentreze cu precădere pe conținutul conceptual al proiectelor. Spațiul, forma și atmosfera sunt țintele principale și sunt prezentate ca atare la jurizarea finală (Fig. 19).

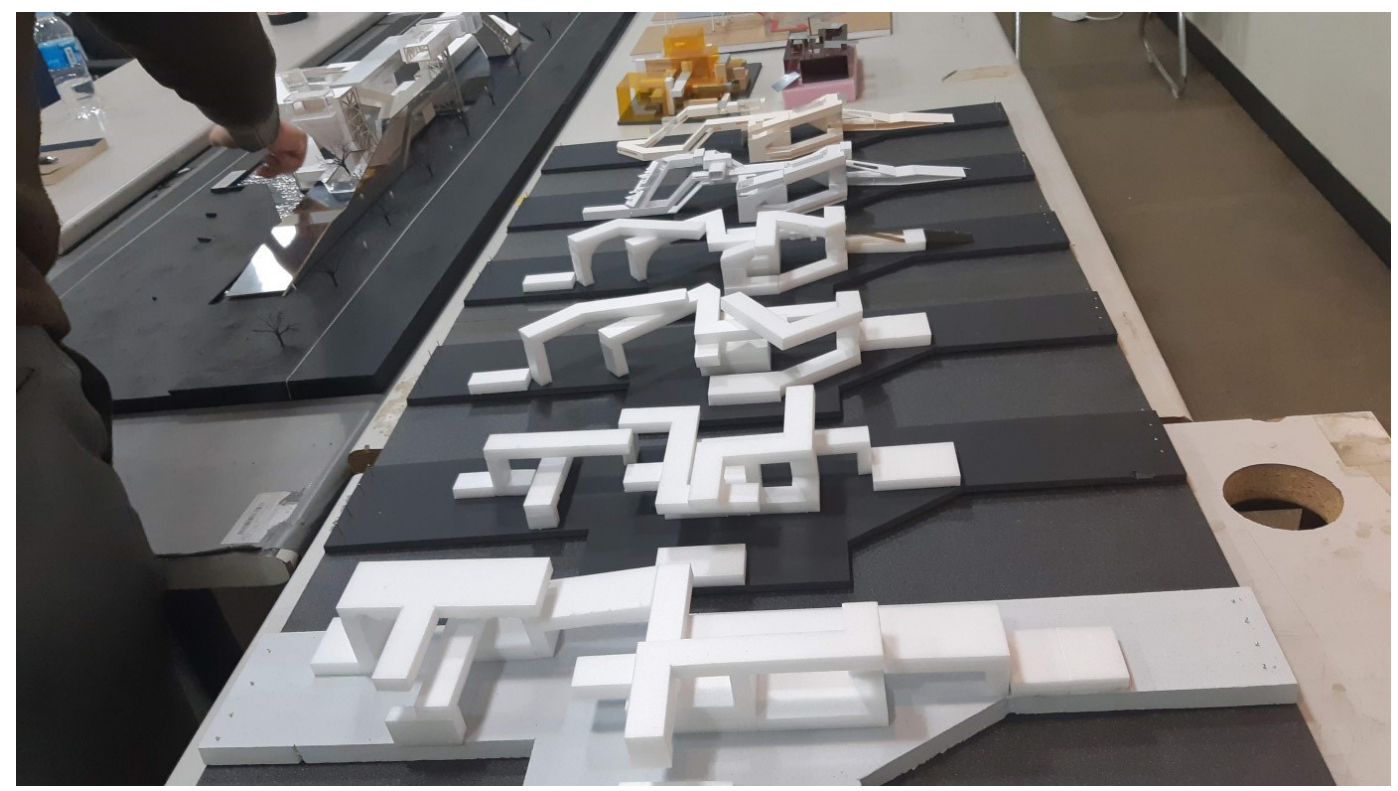

Fig. 19. Jurizarea finală. Machete conceptuale și proiectul propriu-zis.

Părțile tehnice precum structura, instalațiile, materialele, sunt cumva secundare în proiecte, însă, în funcție de situație și de cerințele coordonatorului de atelier, studenții au acces la consiliere de calitate și pe parte tehnică. Complexitatea elaborării proiectelor de anul 3 este comparabilă și uneori superioară proiectelor de diplomă de la noi, mai puțin partea tehnică, legată de structură și detalii de finisare. În fine, programul funcțional este construit pe baza studierii precedentelor construite, ca și la noi. 


\section{SEMINARE, WORKSHOPURI ȘI CONFERINȚE}

În afara coordonării atelierului de arhitectură, activitatea mea a conținut și susținerea, în cadrul Departamentului de design integrat (Department of U-Design), a unei serii de seminare și workshopuri (Fig. 20) reunite sub umbrela termenului de Well-being din cadrul cursului de Medical Humanities. Seminarele s-au adresat studenților postuniversitari din domeniul designului medical, video și packaging, și au avut următoarele tematici:

- Arhitectură și îmbrăcăminte;

- Corp și frumusețe;

- Grădina și spitalul;

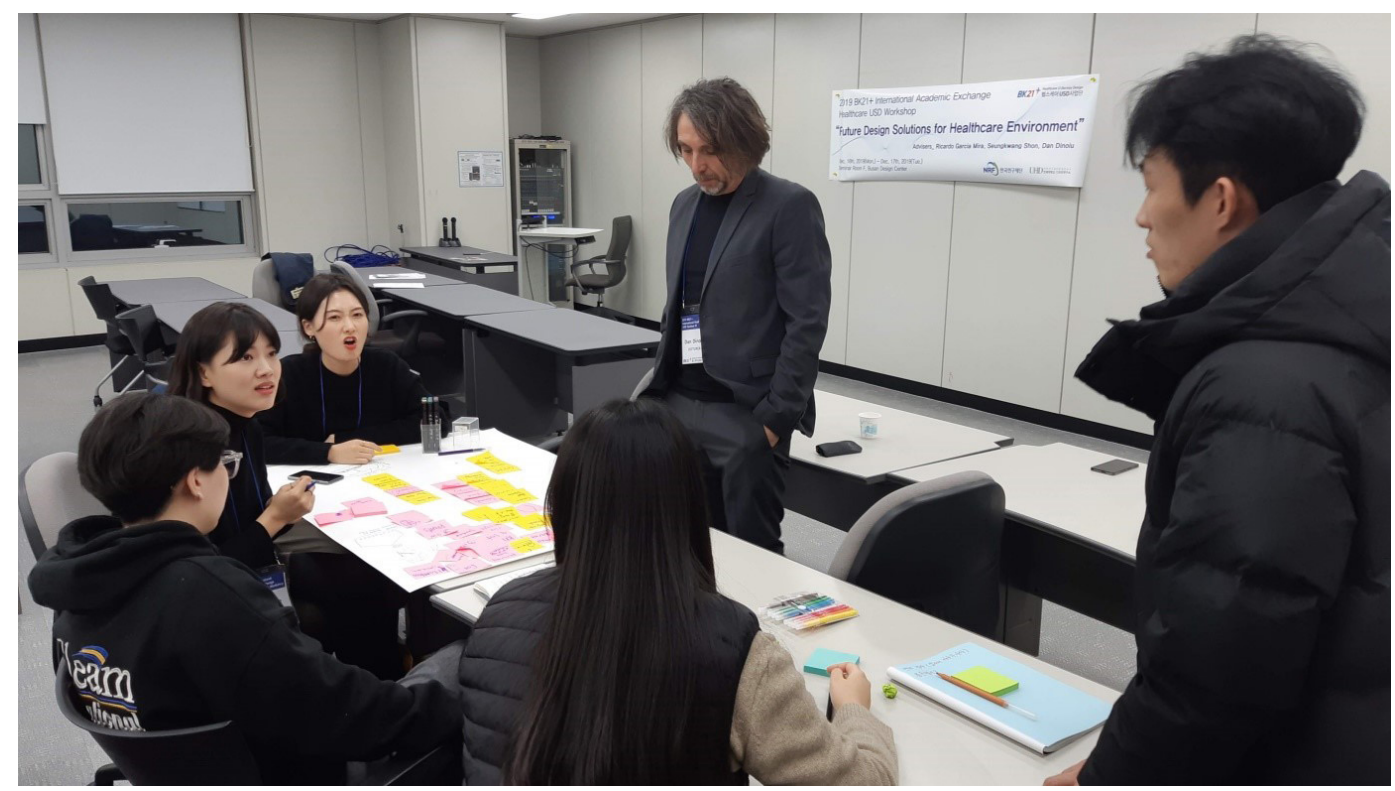

Fig. 20. Workshop susținut in cadrul BK21+ International Healthcare USD Seminar III / Multilateral Solutions for Healthcare Environment.

Activitatea în acest departament a inclus și participarea la doua conferințe, una cu tema Collective Housing and Well-being: From Ocean Liner to Hive Community, însoțită de un workshop, în cadrul BK21+ International Healthcare USD Seminar III / Multilateral Solutions for Healthcare Environment, organizat de Inje University la Busan Design Center, Busan, și alta cu tema The Architecture of Communication, în cadrul BK21+ International 
Healthcare USD Seminar II / Communicative Urban Spaces, organizat de Inje University în campusul din Gimhae, unde am avut ocazia să fac cunoscută universitatea noastră și activitatea noastră de aici. (Fig. 21, 22).

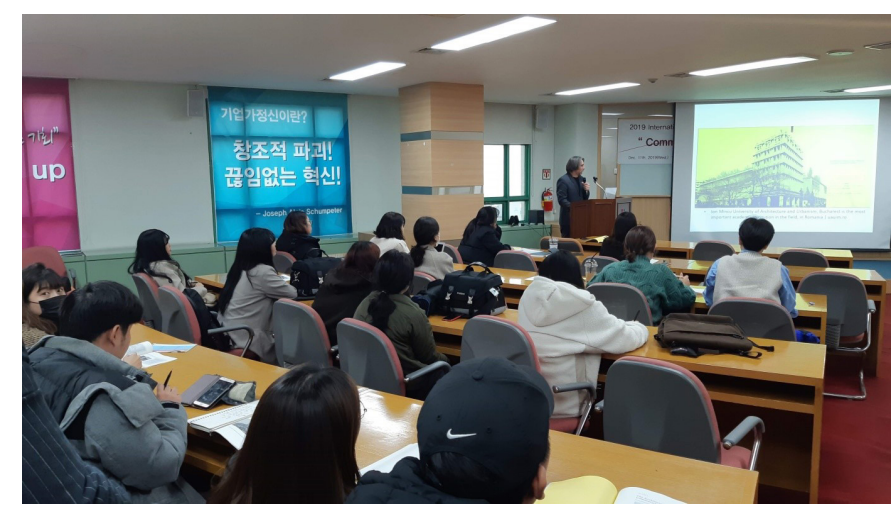

Fig. 21. Conferința The Architecture of Communication, în cadrul BK21+ International Healthcare USD Seminar II / Communicative Urban Spaces

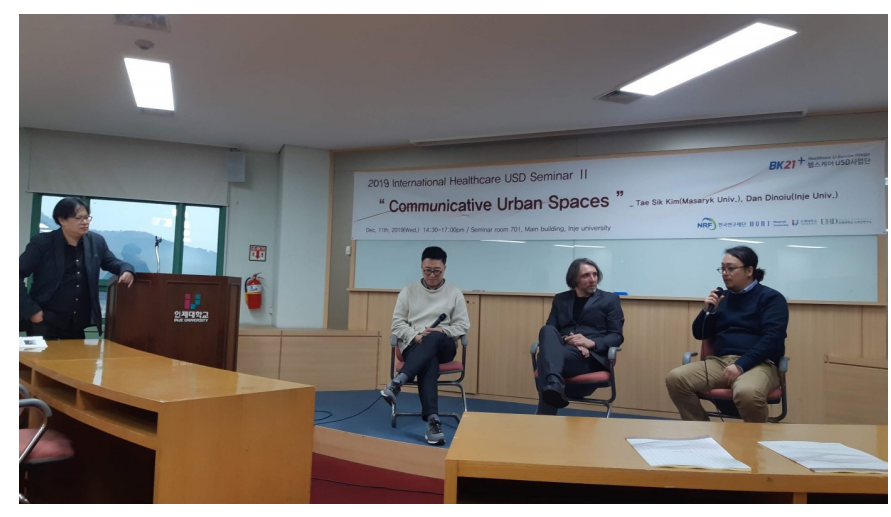

Fig. 22. Conferința The Architecture of Communication, în cadrul BK21+ International Healthcare USD Seminar II / Communicative Urban Spaces

\section{OBSERVATIII FINALE}

Observațiile de mai jos sunt o recapitulare a celor descrise pe parcursul materialului de față. Ele se referă cu predilecție la activitatea cea mai importantă pe care am avut-o, cea de la atelier. Evident, sunt observații și impresii subiective, uneori parțiale, datorită faptului că în Coreea extrem de puțină lume vorbește confortabil limba engleză. în consecință, comunicarea directă este mult îngreunată, atât cu studenții cât și cu profesorii.

Aceste observații pot fi sau nu motiv de reflecție, dar în orice caz sunt elemente care fac în opinia mea o diferență între noi și ei.

- Studenții sunt expuși unui mediu arhitectural, urbanistic și cultural superior celui din București, din care conferințele și expozițiile fac parte integrantă. Universitatea organizează permanent conferințe și worshopuri precum și vizite de studiu la Busan și Seoul.

- Coordonatorii sunt titulari cu contract ai universității, recrutați din rândul tinerilor profesioniști cu rezultate (proiecte laureate, concursuri câștigate). Aceștia renunță în mod imperativ la cariera profesională pe perioada contractului pentru a se ocupa exclusiv de activitatea universitară. 
Acest aspect mărește gradul de adeziune al cadrelor universitare și, probabil, al studenților față de școală.

- Grupele sunt mici, de 10-12 studenți, în așa fel încât coordonatorul atelierului poate vorbi suficient cu fiecare student, pe parcursul unui atelier.

- Grupele au un singur coordonator, astfel se evită situația des întâlnită la noi, în care un student se plimbă pe la mai mulți îndrumători de unde pleacă cu idei contradictorii și chiar confuze.

- Coordonatorul atelierului este cel care acordă nota finală propriilor studenți, după o juriere comuna cu ceilalți coordonatori de ateliere. În acest fel, studenții sunt antrenați permanent să își asume riscuri și să fie criticați fără să fie pedepsiți la notă.

- Studenții sunt încurajați să dezvolte concepte spațiale, formale și funcționale inovative, complexe, fără să țină cont de limitările tehnice ale proiectelor (structura, instalații etc).

- Studenții au opțiunea de a alege la începutul semestrului grupa unde doresc să meargă, în anumite limite.

- Pregătirea umanistă și artistică a studenților coreeni pare mai bună, iar teoriile la care sunt expuși prin intermediul conferințelor și seminarelor includ tematici noi și actuale.

- Fiecare proiect durează un semestru, în acest fel existând timpul necesar dezvoltării lui complete.

- Faza conceptuală este extrem de amplă, iar jurizarea intermediară a proiectelor, făcută în comun de coordonatorii atelierelor, se desfășoară la un nivel intelectual remarcabil și este foarte eficientă.

- Predările sunt însoțite de extrem de multe machete, care demonstrează dincolo de orice dubiu profunzimea studiului spațiului și al expresiei. 


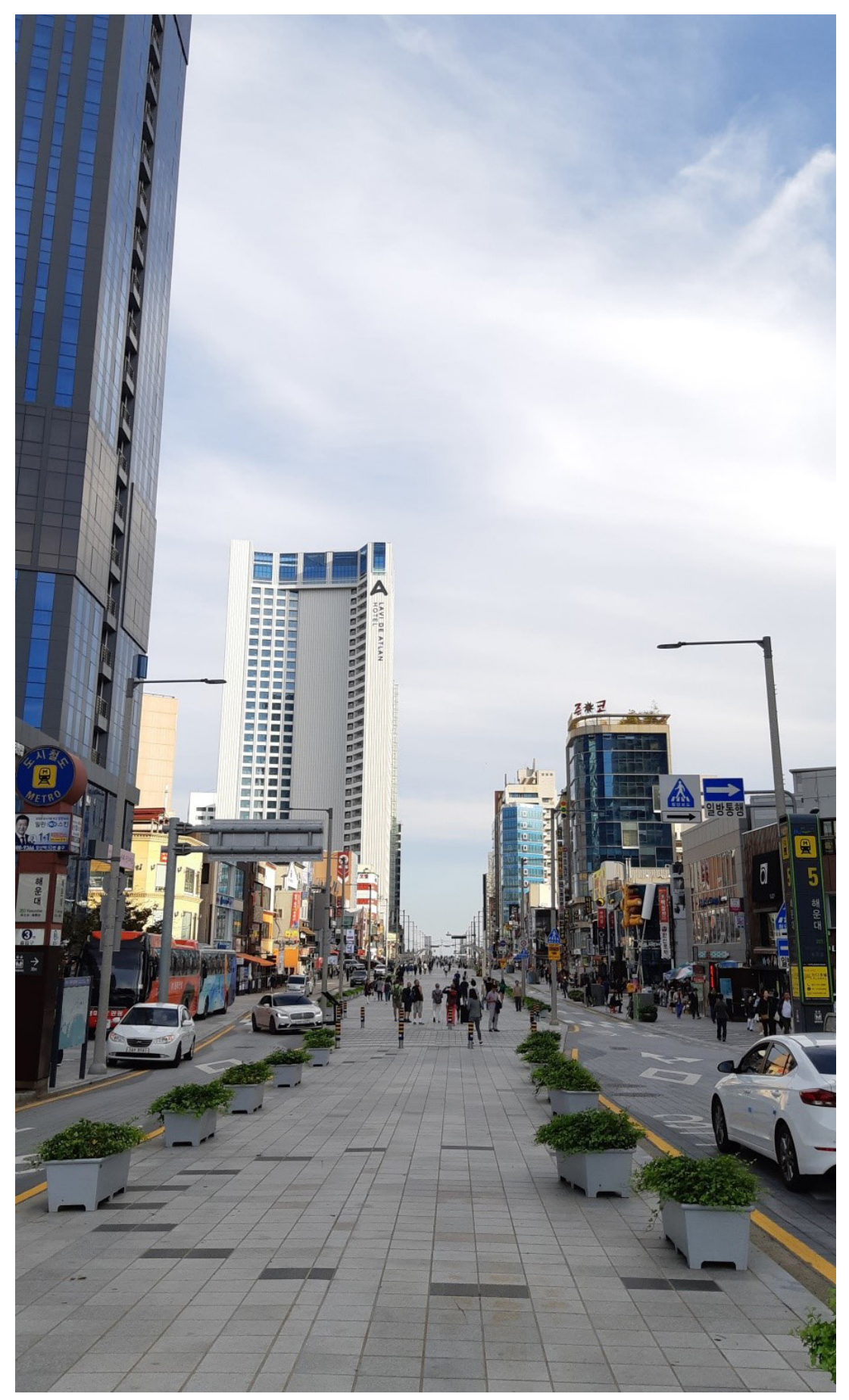

